\title{
Effects of Storage Temperature on the Keeping Quality of Malabar Spinach (Basella alba L.)
}

\author{
Enriquez Fabio Gimena*, Kawada Kazuhide* and Matsui Toshiyuki* \\ * Department of Bioresource Production, Faculty of Agriculture, Kagawa University \\ Ikenobe 2393, Miki, Kagawa 761-0795
}

\begin{abstract}
The influence of storage temperature on freshness, ascorbic acid content, respiration rate, ion leakage from leaf tissue discs and morphological changes of malabar spinach (Basella alba L.) were investigated. At $25^{\circ} \mathrm{C}$ storage, yellowing of the leaves was mainly responsible for the quality deterioration and lost $50 \sim 60 \%$ in ascorbic acid content after $4 \sim 6$ days. Those stored at 0 and $5{ }^{\circ} \mathrm{C}$, however, were still green and lost $26 \sim 36 \%$ after $12 \sim 14$ days. Lower temperatures were effective in decreasing the yellowing, ascorbic acid loss and the respiration rate. However, upon transfer to $25^{\circ} \mathrm{C}$, the $\mathrm{CO}_{2}$ production increased rapidly and significantly higher increases were observed from those stored at 0 and $5^{\circ} \mathrm{C}$ than those stored at 10 or $15^{\circ} \mathrm{C}$. This respiratory stimulation was positively correlated with the increase in the rate of ion leakage at 0 and $5^{\circ} \mathrm{C}$. Chilling injury was observed in storage at 0 or $5^{\circ} \mathrm{C}$ and was manifested as pitting and softening (loss of turgidity) of leaves. Stomata were the only openings on the epidermis of the leaves and frequencies were greater on the abaxial surface than on the adaxial surface. Cracking of the tissue near the stomata and exudates outside the stomata were observed after $12 \sim 14$ days of storage at 0 and $5^{\circ} \mathrm{C}$.
\end{abstract}

(Received Feb. 15, 2000 ; Accepted Jun. 12, 2000)

Malabar spinach, tsurumurasaki in Japanese is a green leafy vegetable of tropical origin which contains more vitamin $\mathrm{A}, \mathrm{C}$ and calcium than spinach and chinese cabbage ${ }^{1}$. Young leaves are occasionally harvested and cut into pieces and utilized like spinach. Recently, malabar spinach has been grown in Shikoku Island (Japan) starting in April and harvested from July to October. However, the keeping quality of malabar spinach is not well known yet.

Fresh fruits and vegetables as living tissues are subject to continual changes after harvest. Such changes cannot be stopped but can be controlled within certain limits by using various postharvest procedures. Temperature management is the most important tool to extend the shelf life and maintain the quality of fresh fruits and vegetables. Above freezing point, for non-chilling- sensitive commodities, every increase in temperature of $10^{\circ} \mathrm{C}$ accelerates deterioration and increases the rate of loss in nutritional quality by 2 to $3 \mathrm{fold}^{2}$. Many plants indigenous to the tropics and subtropics and some tissues from plants of temperate origin are injured by exposure to nonfreezing temperatures below $12^{\circ} \mathrm{C}^{3) \sim 5}$. This physiological disorder is referred to as chilling injury (CI) and has been of great concern for many years with harvested plant parts. HiRATA et $a l .^{6)}$ reported that $\mathrm{CI}$ in malabar spinach developed in storage at $1^{\circ} \mathrm{C}$ and was manifested as pitting and softening of the leaves. The ascorbic acid content decreased rapidly at low temperature occurring $\mathrm{CI}^{6,7)}$. Plants, depending on their genetic origin and general physiological status, differ in chilling sensitivity. Although storage time and shelf life of some crops can be prolonged by 
lowering the storage temperature, $\mathrm{CI}$ is induced with chilling sensitive commodities, which influences the quality of stored products. Many physiological responses to various stimuli in plant tissues have been ascribed to changes in membrane permeability. CI has been shown to increase membrane permeability, as measured by solute leakage and ion uptake, in tissues from various chilling sensitive species ${ }^{4), 8}$.

Our objective was to clarify the postharvest characteristics of malabar spinach. The influence of storage temperature on freshness, ascorbic acid content, respiration rate, ion leakage and morphological changes were determined.

\section{Materials and Methods}

\section{Plant material}

About 25 30 cm malabar spinach shoots were obtained from a grower in Takamatsu, Kagawa, Japan. The sample shoots were harvested early in the morning and brought immediately to the Laboratory. The samples which were free from defects were selected and used in the experiment. Malabar spinach were put in polyethylene bags and stored at $0,5,10,15$ and $25^{\circ} \mathrm{C}$, taken out at 4 , 7, 10 and $14 \mathrm{~d}$ and then transferred to $25^{\circ} \mathrm{C}$ for 2 days.

\section{Respiration rate measurement}

About 100 to $600 \mathrm{~g}$ of malabar spinach were placed in a 6 liter glass jar and placed at different storage conditions. To measure production of $\mathrm{CO}_{2}$, malabar spinach leaves were enclosed in glass jars at different temperatures for an appropriate length of time for $\mathrm{CO}_{2}$ to accumulate to measurable levels (about $1 \mathrm{~h}$ ). Five-milliliter triplicate samples were taken from the headspace of the sealed jars through the septum and were injected into a Shimadzu GC-8AIT gas chromatography (GC) equipped with a thermal conductivity detector (TCD) with helium as carrier gas at a flow rate of $20 \mathrm{\ell} / \mathrm{min}$. The results were expressed as $\mathrm{m} \ell \mathrm{CO}_{2} \mathrm{~kg}^{-1} \mathrm{~h}^{-1}$. After the designated exposure period, the subsamples of malabar spinach were taken out from the different storage conditions and placed at $25^{\circ} \mathrm{C}$. After 2 days, respiration rate of the transferred sample was measured.

\section{Ascorbic acid analysis}

L-Ascorbic acid (AsA) was determined by the 2,4-dinitrophenylhydrazine method described by JosePh et $a l^{9)}$. Five $g$ flesh from malabar spinach leaves was grinded in a mortar and pestle with 1 $\mathrm{g}$ sea sand, added with $20 \mathrm{~m} \ell 5 \%$ metaphosphoric acid and $25 \mathrm{~m} \ell$ deionized water. The homogenate was centrifuged at $1,000 \mathrm{rpm}$ for $10 \mathrm{~min}$. The supernatant was used for ascorbic acid measurement. Color intensity of osazone derived from dehydroascorbic acid was measured at $530 \mathrm{~nm}$ by using a double beam spectrophotometer UVIDEC -320 , Japan. The amount of AsA as reduced ascorbic acid was calculated by subtracting the amount of dehydroascorbic acid from that of the total ascorbic acid.

\section{Assessment of Ion Leakage}

A technique for assessing ion leakage described by FURMANSKI and BUESCHER ${ }^{10)}$ was used with some modifications. Leaf tissue discs were prepared by slicing cylinders using a cork borer (16 $\mathrm{mm}$ diameter). After slicing, the discs were washed 3 times with distilled water and immersed in a $100 \mathrm{~m} \ell$ of $0.4 \mathrm{M}$ mannitol solution. Beakers with the samples were put in double shakers with agitation at 100 cycles $\min ^{-1}$ for $5 \mathrm{~h}$ at $25^{\circ} \mathrm{C}$. Ion leakage was determined with a conductivity bridge (cell constant of. 940) after 1 and $5 \mathrm{~h}$ of incubation. The conductance was again determined after boiling the sample for $5 \mathrm{~min}$ and cooled to $30^{\circ} \mathrm{C}$ before measurement. The results were expressed as percentage (\%) total ion leakage, i. e., initial reading/final reading $\times 100$.

\section{Scanning Electron Microscope}

Leaf tissue discs were fixed in $4 \%$ glutaldehyde in $0.2 \mathrm{M}$ phosphate buffer at $\mathrm{pH} 7$ for $24 \mathrm{~h}$ at $5^{\circ} \mathrm{C}$. The discs were rinsed 3 times with the same phosphate buffer with an interval of $16 \mathrm{~h}$ and then post-fixed with $1.6 \%$ osmium tetroxide for $3 \mathrm{~h}$ at $5^{\circ} \mathrm{C}$. After 3 times washing with the same buffer with an interval of $8 \mathrm{~h}$, the leaf discs were then dehydrated in an ethanol series at $30,50,70 \%$ for 30 min each ; 85 and $95 \%$ for 60 min each and 
$100 \%$ for $24 \mathrm{~h}$. After the ethanol series, 50 and $100 \%$ iso-amyl acetate was used for $12 \mathrm{~h}$ each. The leaf discs were then dried using a Hitachi $\mathrm{HCP}-1$ critical point drier in liquid carbon dioxide and mounted in an aluminum stubs (SEM cells) with a drop of silver paste. The SEM cells with the sample were coated with gold palladium in an ion sputter coater (RMC-Eiko Corp). The coated leaf discs were observed in a Hitachi S-800 scanning electron microscope at $8 \mathrm{kV}$ accelerating voltage.

\section{Statistics}

Determinations of the effects of the different storage temperatures on the respiration rate, ion leakage and the loss of the ascorbic acid content were conducted in triplicate and analyzed statistically using a completely randomized design (CRD). Treatment means were compared using the least significant difference test.

\section{Results and Discussion}

\section{Respiration rate}

Changes in respiration rate of malabar spinach during storage at each temperature and after transfer to $25^{\circ} \mathrm{C}$ are shown in Fig. 1. The respiration rate of malabar spinach stored at $25^{\circ} \mathrm{C}$ was higher than that at the other storage temperatures on the day of harvest, but the difference became smaller as the storage progressed. However, upon transfer of malabar spinach to $25^{\circ} \mathrm{C}, \mathrm{CO}_{2}$ production increased rapidly especially after storage at 0 and $5^{\circ} \mathrm{C}$ with those harvested both in July and October. The increase of $\mathrm{CO}_{2}$ production was greater with malabar spinach harvested in October than in July. The stimulation appeared after 4 days and was more apparent with longer storage. A similar result on cucumber leaves was reported by LYONS $^{4}$ and suggested that the stimulated production at warm temperature after transfer from various chilling temperature might be due to the accumulation of certain metabolic intermediates during the exposure to chilling. This respiratory stimulation upon transfer has been observed in many plant species ${ }^{11)}$, but with chilling-sensitive species it is

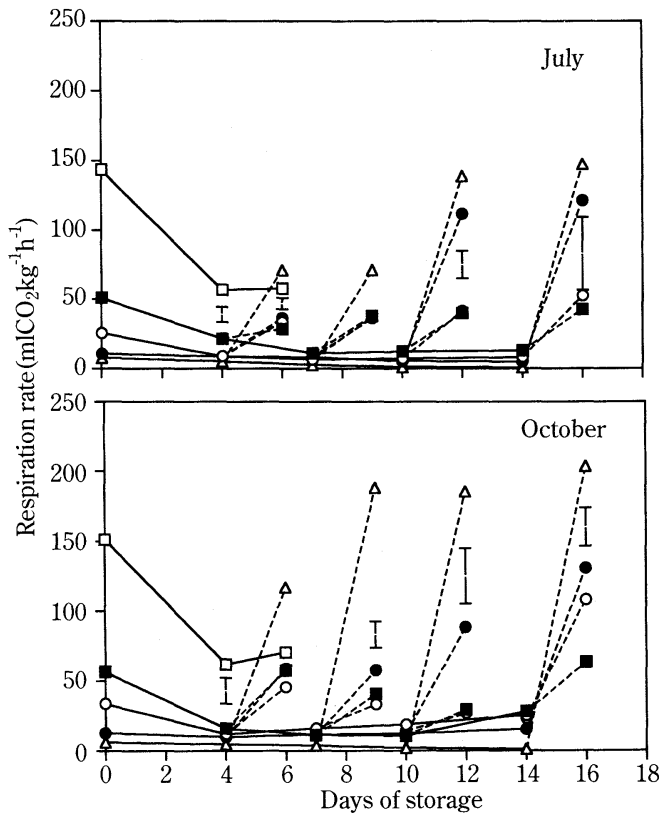

Broken lines represent transfer to $25^{\circ} \mathrm{C}$. Vertical bars represent LSD (0.05).

$\longrightarrow 0^{\circ} \mathrm{C} \longrightarrow 5^{\circ} \mathrm{C} \longrightarrow-10^{\circ} \mathrm{C} \longrightarrow-15^{\circ} \mathrm{C} \longrightarrow \square-25^{\circ} \mathrm{C}$

Fig. 1 Changes in respiration rate of malabar spinach harvested in July and October, held at different storage temperatures and transferred to $25^{\circ} \mathrm{C}$ for 2 days

greatly amplified and can be used as an index of the severity of CI in those tissues. CI of malabar spinach was manifested as pitting and softening (loss of turgidity) of leaves. Malabar spinach exposed for $7 \mathrm{~d}$ at $0^{\circ} \mathrm{C}$ or $10 \mathrm{~d}$ at $5^{\circ} \mathrm{C}$ appeared to be the maximum storage days at each temperature before the occurrence of chilling injury symptoms. The development of CI was parallel to an increase in respiration with a longer exposure at chilling temperature.

\section{Ascorbic acid content}

Fig. 2 shows the percent loss of AsA content of malabar spinach harvested in July and October, held at various temperatures, and then transfer to $25^{\circ} \mathrm{C}$ for 2 days. The loss of AsA was relatively higher with malabar spinach harvested in July than in October and was more pronounced at 15 or $25^{\circ} \mathrm{C}$ than at 0,5 or $10^{\circ} \mathrm{C}$. At $25^{\circ} \mathrm{C}$ storage, the ascorbic acid loss was about $50 \sim 60 \%$ after $4 \sim 6$ days, while those stored at 0 or $5^{\circ} \mathrm{C}$ had a loss of about $20 \sim 36 \%$ within $12 \sim 14$ days of storage. 


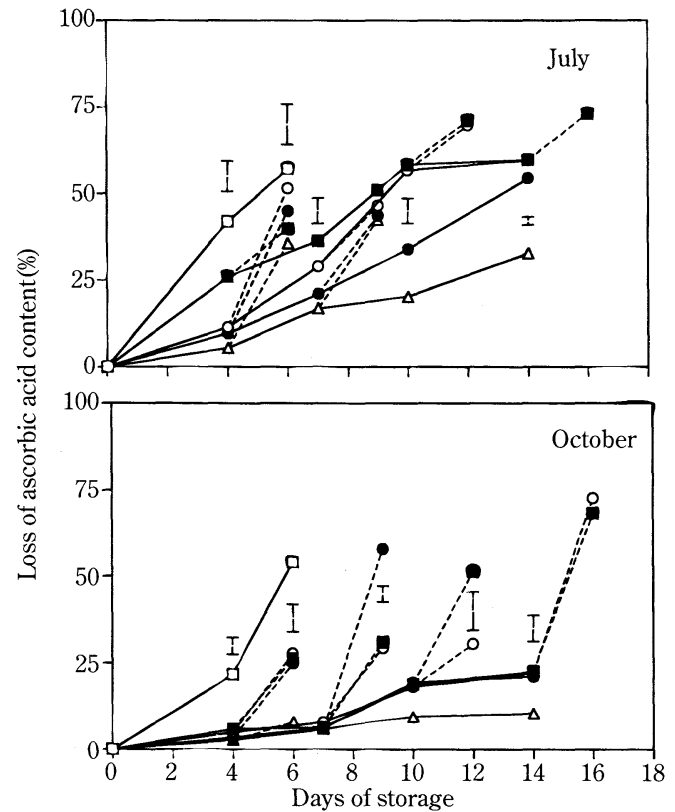

Broken lines represents transfer to $25^{\circ} \mathrm{C}$. Vertical bars represent LSD (0.05). Initial AsA content, 164.86 and $171.72 \mathrm{mg} \%$ for July and October, respectively.

$\longrightarrow 0^{\circ} \mathrm{C} \longrightarrow 5^{\circ} \mathrm{C} \longrightarrow-10^{\circ} \mathrm{C} \longrightarrow-15^{\circ} \mathrm{C} \longrightarrow-25^{\circ} \mathrm{C}$

Fig. 2 Loss of ascorbic acid content (\%) of malabar spinach harvested in July and October, held at different storage tempertures and transferred to $25^{\circ} \mathrm{C}$ for 2 days

YAMAUCHI ${ }^{12)}$ reported that yellowing of spinach leaves was associated with an increase in peroxidase enzyme activity which caused the decrease in AsA. The decrease of AsA in yellowing spinach stored at $1^{\circ} \mathrm{C}$ was found to be the interaction of ascorbate oxidase and peroxidase enzymes ${ }^{12}$. Moreover, HAARD ${ }^{13)}$ reported that ascorbate oxidase and peroxidase activities increased with the development of CI. After transfer from storage at 10 or $15^{\circ} \mathrm{C}$ for $4 \mathrm{~d}$ to $25^{\circ} \mathrm{C}$ for 2 days, the AsA loss was relatively higher than those stored at 0 or $5^{\circ} \mathrm{C}$. However, after transfer from $7 \mathrm{~d}$ storage at 5 to $25^{\circ} \mathrm{C}$, a significantly higher loss was observed with pitting and wilting of the leaf tissue. In addition, malabar spinach stored at 0 or $5^{\circ} \mathrm{C}$ for 10 or $14 \mathrm{~d}$, deteriorated so rapidly upon transferred to $25^{\circ} \mathrm{C}$ where AsA was unmeasurable. Leaf tissue which was severely injured by exposure to low temperatures may be largely the result of autolysis of the cells ${ }^{14}$. However, with continuous storage at $0^{\circ} \mathrm{C}$ for $14 \mathrm{~d}$ had the lowest ascorbic acid loss compared with those stored at 5,10 or $15^{\circ} \mathrm{C}$. The loss was relatively higher in July than in October harvest. In spinach harvested in autumn, ascorbic acid losses were higher compared to those harvested in spring and winter ${ }^{15)}$, which was in agreement with ScoTT and KRAMER $^{16)}$ on beans, peas, spinach and asparagus in which the magnitude of loss varies depending on the product and the harvest date.

\section{Rate of ion leakage}

Discs of malabar spinach leaf tissue held at different temperatures resulted in a progressive increase in ion leakage with a decrease in temperature (Fig. 3). The chilling temperature at 0 or $5^{\circ} \mathrm{C}$ caused a steady increase in the rate of ion leakage with time. The results were comparable with the reports of WRIGHT and SIMON ${ }^{17}$ and WRIGHT $^{18)}$ on sweet potato and leaves of

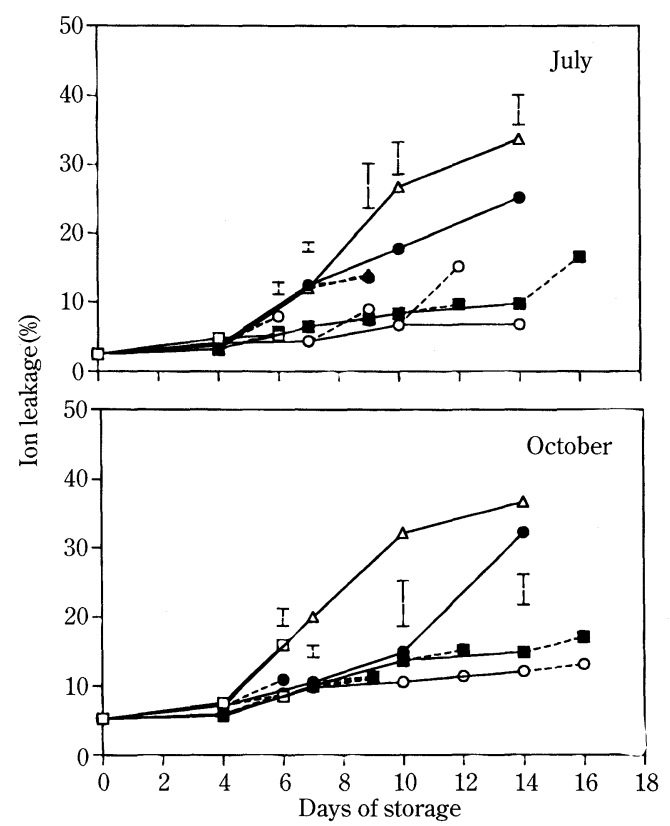

Broken lines represent transfer to $25^{\circ} \mathrm{C}$. Vertical bars represent LSD $(0.05)$

$\longrightarrow 0^{\circ} \mathrm{C} \longrightarrow 5^{\circ} \mathrm{C} \longrightarrow-10^{\circ} \mathrm{C} \longrightarrow-15^{\circ} \mathrm{C} \longrightarrow \square-25^{\circ} \mathrm{C}$

Fig. 3 Changes in the rate of ion leakaga (\%) from leaf discs of malabar spinach harvested in July and October, held at different storage tempertures and transferred to 25 ${ }^{\circ} \mathrm{C}$ for 2 days 


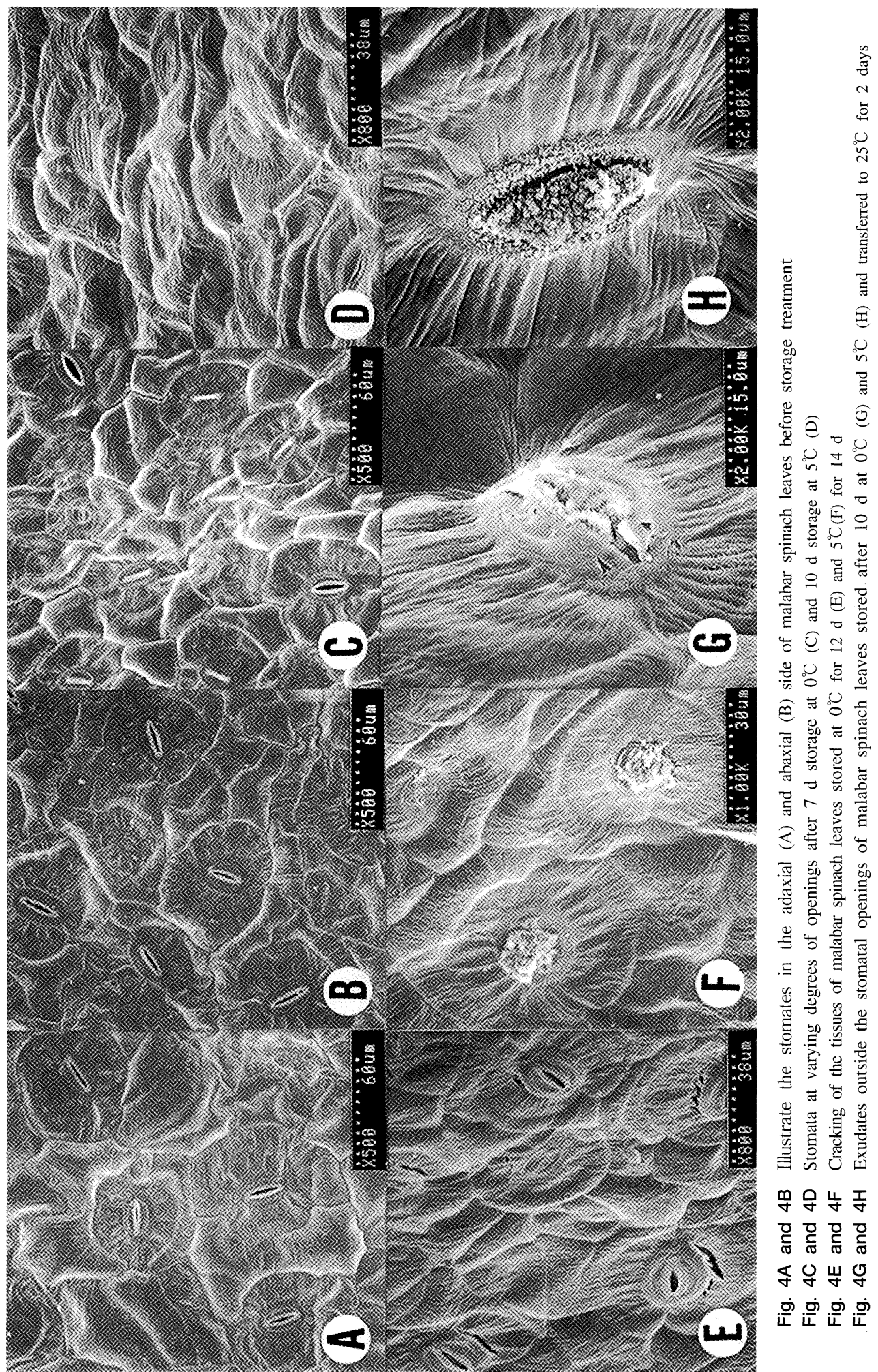


cucumber and beans in which there was a rapid increase in ion leakage upon exposure at chilling temperatures. The predominantly increased leakage from malabar spinach tissue stored at 0 and $5^{\circ} \mathrm{C}$ may result from an impairment of cell permeability. LEVITT $^{19}$ suggested that CI may have been caused by a change in cell permeability. In addition, YAMAWAKI et $a l .{ }^{20)}$ reported that there was a continuous increase of ion leakage before the occurrence of CI. Ion leakage may serve as an index of susceptibility to CI. On the other hand, ion leakage from the leaf discs stored at 10 or $15^{\circ} \mathrm{C}$ remained at a low level throughout the storage period. The data after transfer to $25^{\circ} \mathrm{C}$ from chilling temperature at 0 or $5^{\circ} \mathrm{C}$ for 7,10 and $14 \mathrm{~d}$ were not available since malabar spinach deteriorated rapidly with severe breakdown of the tissue.

\section{Scanning Electron Microscope (SEM) photomicrograph}

Surface features of malabar spinach as viewed by SEM includes stomata, exudates and cracking of tissues (Fig. 4). Fig. 4A and $4 \mathrm{~B}$ illustrate the stomata in the adaxial and abaxial surfaces of the leaves of malabar spinach before the storage treatments. Stomatal frequencies were greater on the abaxial surface than on the adaxial surface. Stomata were the only natural openings observed in the epidermis because no trichomes or other natural openings were seen. Stomata were open to varying degrees after 7 and 10 days storage at different temperatures (Fig. 4C $\sim 4 \mathrm{E}$ ). $\mathrm{KAYS}^{21}$ reported that stomatal closure represents a means of conserving water within the tissue. When plant parts are detached at harvest from the parent plant, the supply of water from the root system is eliminated and stomata would decrease their aperture opening markedly. Since stomata were the only natural openings observed in malabar spinach leaves, they should be important in regulating moisture loss. On the other hand, LYONS ${ }^{4)}$ reported that stomata in some instances were unable to close at chilling temperature and the ability of leaves to transport water was impaired.
Cracking of the tissues were noticed from malabar spinach stored at $0^{\circ} \mathrm{C}$ for 12 days and $5^{\circ} \mathrm{C}$ for 14 days (Fig $4 \mathrm{E} \sim 4 \mathrm{~F}$ ). The injury may be due to inability of the relatively inflexible metabolic cells to function at low temperatures. When they were stored for 12 days ( $10 \mathrm{~d}$ storage $+2 \mathrm{~d}$ at $25^{\circ}$ C) at 0 or $5^{\circ} \mathrm{C}$, the tissues near the stomata began to crack and some exudates were formed outside the stomatal openings probably due to some leakage (Fig. $4 \mathrm{G} \sim 4 \mathrm{H}$ ). The stomata became disorganized and disintegrated and subsequently large exudates around the stomata were observed. The cracking of the tissue was more serious at $0^{\circ}$ $\mathrm{C}$, whereas at 5 and $10^{\circ} \mathrm{C}$ exudates outside the stomata were rampant. MoLINE ${ }^{22)}$ described that if the temperature of the chilling sensitive plant is lowered to the critical temperature (below $10^{\circ} \mathrm{C}$ ), membrane lipids may solidify, contract and break, thus destroying selective membrane permeability.

In conclusion, low temperatures at 0 and $5^{\circ} \mathrm{C}$ were effective in decreasing the respiration rate and ascorbic acid in storage of malabar spinach. Malabar spinach, however, is susceptible to chilling injury and can be kept fresh for a maximum of $7 \mathrm{~d}$ at $0^{\circ} \mathrm{C}$. At $25^{\circ} \mathrm{C}$, yellowing of the leaves was mainly responsible for quality deterioration in 4 to 6 days. As observed with SEM, stomata were the only openings on the epidermes of the leaves.

Acknowledgments The first author would like to thank the Ministry of Education Culture and Sports for the scholarship grant. To Takashi TOKUDA for his technical assistance on tissue observation by scanning electron microscope and to da Silva Jaime Texiera for critical review of the manuscript.

\section{References}

1) Anonymous.: Standard Tables of Food Composition in Japan 4th ed. (Resources Council, Sci. and Tech. Agency, Japan) (1982)

2) Kader, A. A.: Proceedings 1st Intl. Symp. on Hort. and Human Health (Prentice-Hall, Englewood Cliffs. N. J.), pp. 18 32 (1987) 
3) Couey, H. M.: HortScience, 17, 162 (1982)

4) Lyons, J. M.: Annu. Rev. Plant Physiol., 24, 445 (1973)

5) Saltveit, Jr., M. E. and Morris, L. L.: Chilling Injury of Horticultural Crops (WANG, Chien Yi ed.) (CRC Press, Boca Raton), pp.3 $\sim 15$ (1990)

6) Hirata, K., Chachin, K and Inata, T.: Nippon Shokuhin Kogyo Gakkaishi, 34, 566 (1987)

7) Ose, K., Chachin, K and Iwata, T.: Food Pre. Sci., 24, 315 (1998)

8 ) Liebermann, M., Craft, C. C. and Wilcox, M. S.: Plant Physiol., 33, 307 (1958)

9) Joseph, H. R., Mary, B. M., Oesterling, M. J. and Damron, C. M.: J. Biol. Chem., 174, 201 (1948)

10) Furmanski, J. and Buescher, R. W. : HortScience, 14, 167 (1979)

11) Eaks, I. L.: Plant Physiol., 35, 632 (1960)

12) Yamauchi, N. and Ogata, K.: J. Japan Soc. Hort Sci., 47, 121 (1978)

13) HaArd, N. F. and Timbie, D.: J.Food Sci., 38, 642 (1973)

14) Miller, E. V. and Heilman, A. S.: Science, 116, 505 (1952)

15) Fennema, O.: Food Technol., 31, 32 (1977)

16) Scott, L. E. and Kramer, A.: Proceedings $J$. Am. Soc. Hort. Sci., 54, 357 (1949)

17) Wright, M. and Simon, E. W.: J. Exp. Bot., 24, 400 (1973)

18) Wright, M.: Planta., 120, 63 (1974)

19) Levitt, J.: Responses of Plants to Environmental Stresses (Acad. Press, NY.), pp. 38 40 (1972)
20) Yamawaki, K., Yamauchi, N., Chachin, K. and Iwata, T.: J. Jpn. Soc. Hortic. Sci., 52, 93 (1983)

21) Kays, S. J.: Postharvest Physiology of Perishable Plant Products (KAYs, S.J. ed.), p. 23 (1997)

22) Moline, H. E.: Phytopathology, 66, 617 (1976)

\section{ツルムラサキの鮮度保持に及ぼす貯蔵温度の影響}

$$
\begin{gathered}
\text { エンリケス ファビオ ギメナ* } \\
\text { 川田和秀*・松井年行* } \\
\text { *香川大学農学部 }
\end{gathered}
$$

(テ761-0795 香川県木田郡三木町池戸2393)

ツルムラサキ (Basella alba L.) の鮮度保持, アス コルビン酸含量, 呼吸速度, イオン漏出や形態学的変化 に及ぼす貯蔵温度の影響について検討した。貯蔵温度 $25^{\circ} \mathrm{C}$ での品質の低下は葉の黄化が主な原因で, 貯蔵 4 〜6 日後に約 50 ～60\%のアスコルビン酸含量の減少が

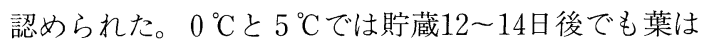
緑色のままでアスコルビン酸の約 $26 〜 36 \%$ を消失した。 低温は黄化，アスコルビン酸の損失や呼吸速度を減らす のに効果的だった。しかしながら， $25^{\circ} \mathrm{C} に 2$ 日間移動

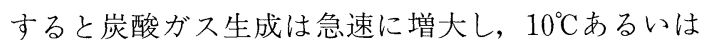
$15^{\circ} \mathrm{C}$ よも $0{ }^{\circ} \mathrm{C}$ と ${ }^{\circ} \mathrm{C}$ て眝蔵した葉は有意に多くの増加

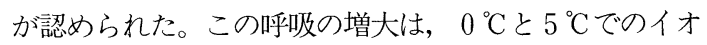
ン漏出速度の増加と関係していた。低温障害は $0{ }^{\circ} \mathrm{C}$ と $5{ }^{\circ} \mathrm{C}$ 貯蔵で認められ，その傷害は葉のピッティングや萎 调（膨圧口ス）であった。気孔は葉の表皮における唯一 の開口部で，その頻度は向軸表面より背軸表面のほうが より多かった。気孔近辺の組織の割れや気孔外部の浸出 物は, $0{ }^{\circ} \mathrm{C}$ と $5{ }^{\circ} \mathrm{C}$ で貯蔵12〜14日後に観察された。

(平成12年 2 月 15 日受付，平成12年 6 月 12 日受理) 